\title{
El Proyecto WYRED
}

\section{WYRED Project}

\author{
Editorial de la revista \\ Francisco José García-Peñalvo \\ Departamento de Informática y Automática / Instituto de Ciencias de la Educación / Grupo GRIAL \\ Director Científico / Editor-In-Chief Education in the Knowledge Society Journal \\ Universidad de Salamanca, España \\ fgarcia@usal.es (http://orcid.org/0000-0001-9987-5584)
}

\section{Resumen}

El proyecto europeo H2020 WYRED (netWorked Youth Research for Empowerment in the Digital society), nació con el objetivo de conocer mejor lo que piensan los jóvenes, escuchando la propia voz de los jóvenes, sobre la influencia de la tecnología en los diversos aspectos de su vida diaria. Actualmente, va camino de culminar su primer año vida, construyendo una aproximación diferente en la investigación en Ciencias Sociales, con un enfoque propio de ciertas áreas de la ciencia abierta como son la ciencia de las masas, la ciencia ciudadana, o la ciencia conectada a una red.

\section{Palabras Clave}

WYRED; Ciencia Abierta; Ciencia Ciudadana; Tecnología; Juventud

\begin{abstract}
WYRED (netWorked Youth Research for Empowerment in the Digital society) European $\mathrm{H2020}$ project was born with the aim of knowing better what young people think, giving them the opportunity of rising their voices, about the technology influence in every aspect of their daily living. Currently, this project is near to finish its first year, building a different Social Sciences research approach, with a focus more oriented to open science related areas such as crowd science, citizen science, or network-connected science.
\end{abstract}

\section{Keywords}

WYRED; Open Science; Citizen Science; Technology; Youth

El proyecto WYRED (netWorked Youth Research for Empowerment in the Digital society) (GarcíaPeñalvo, 2016e; García-Peñalvo \& Kearney, 2016) es un proyecto europeo financiado dentro del Programa H2020 (Ref. 727066) en la línea de las Sociedades inclusivas, innovadoras y reflexivas (H2020-SC6-REV-INEQUAL-2016). El consorcio, liderado por el grupo GRIAL (García-Peñalvo, 2016b; García-Peñalvo, et al., 2012) de la Universidad de Salamanca, comenzó su trabajo en noviembre de 2016, por lo que nos acercamos a su primer año, en el que se ha construido un enfoque de investigación novedoso en el campo de las Ciencias Sociales y que estaría incluido en el concepto de Ciencia Abierta (García-Peñalvo, 2017a, 2017b; García-Peñalvo, García de Figuerola, \& Merlo-Vega, 2010), con una aproximación más cercana a la ciencia ciudadana (Ramírez-Montoya \& García-Peñalvo, 2018).

Específicamente, WYRED tiene como objetivo proporcionar un marco para la investigación en el que jóvenes, entendiendo joven con un rango amplio de edades, puedan expresar y explorar sus 
perspectivas e intereses en relación con la sociedad digital, conjuntamente con una plataforma (García-Peñalvo \& Durán-Escudero, 2017) desde la cual puedan comunicar sus perspectivas a otros actores de manera efectiva, a través de procesos de compromiso innovadores. Para ello, se ha llevado a cabo un ciclo de investigación generativa que ha incluido actividades de creación de redes de contactos, diálogos sociales, actividades de investigación definidas para ellos y fases de interpretación centradas y dirigidas por niños y jóvenes, de las cuales están surgiendo una gama diversa de productos, perspectivas críticas y otras ideas para la toma de decisiones en relación con las necesidades de los niños y jóvenes sobre la sociedad digital.

En la Figura 1 se describe el proceso de investigación que se ha seguido. En la primera fase de preparación diferentes actores han expresado su opinión sobre los aspectos más importantes que ellos piensan que influyen en la definición de la sociedad con la presencia de la tecnología. En la segunda fase se desarrollan los diálogos sociales entre jóvenes para definir qué cuestiones son las más interesantes para centrarse en ellas. En la tercera fase de exploración se desarrollan los proyectos de investigación con un enfoque abierto para buscar respuestas, tanto de forma individual como colectiva, a los interrogantes abiertos. Por último, en la cuarta fase se explican los resultados y se ofrecen recomendaciones a los tomadores de decisiones. Este enfoque cíclico se repetirá otras dos veces más hasta el final del proyecto. De una manera más detallada, la Figura 2 presenta este mismo ciclo.

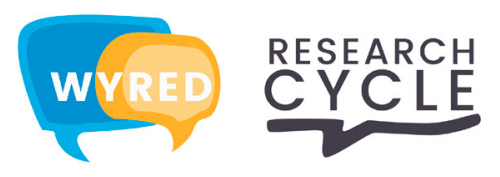

\section{Stakeholders, Children \& Young People}

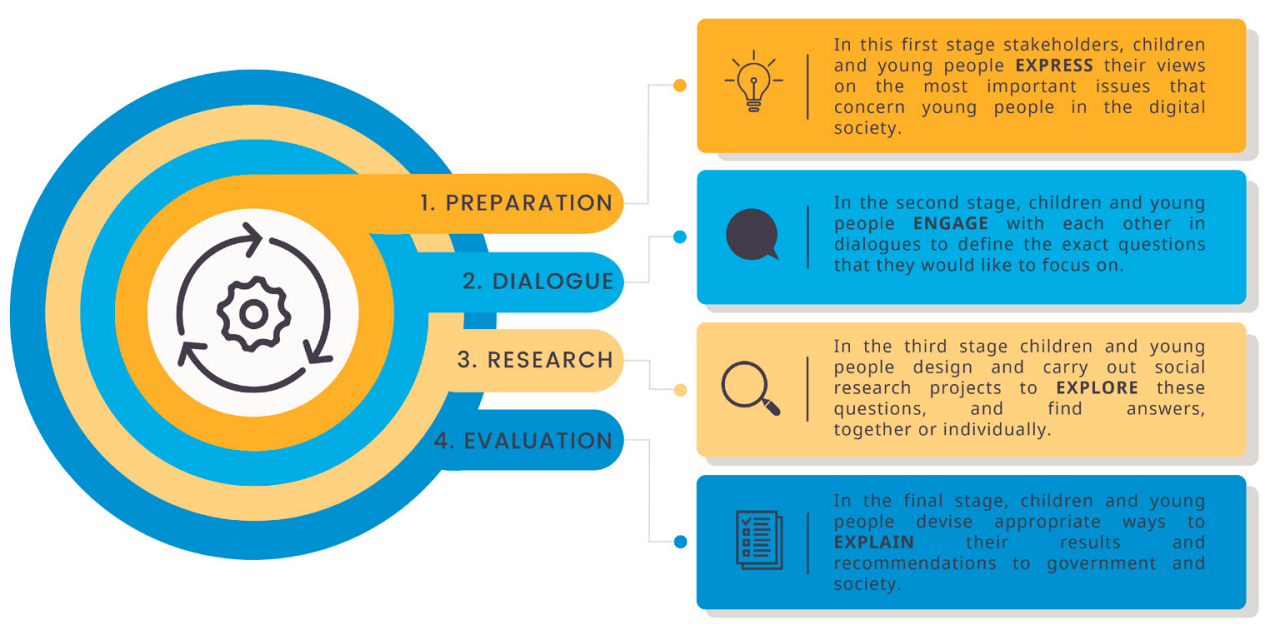




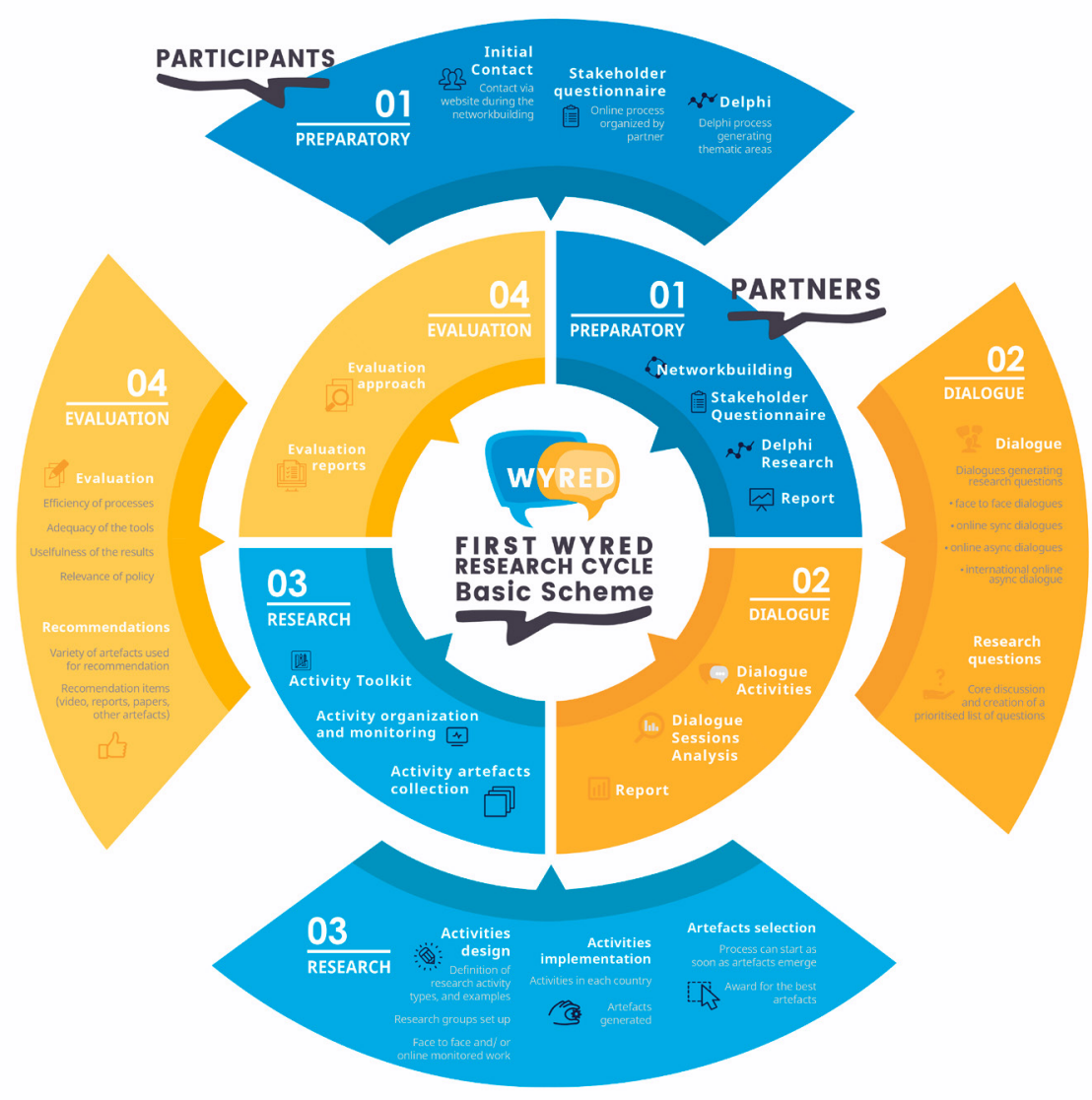

Figura 2. Infografía del ciclo de investigación WYRED (WYRED Consortium, 2017a) Figure 2. WYRED Research Cycle Infographic (WYRED Consortium, 2017a)

\section{Contenido de este número}

El primer artículo de este número lleva por título "Cultura científica desde la universidad. Evaluación de la competencia investigativa en estudiantes de Verano Científico" (Grijalva Verdugo \& Urrea Zazueta, 2017). Este trabajo presenta los resultados de un programa de formación de jóvenes investigadores, los Veranos Científicos, en el estado de Sinaloa, México.

Santos et al. (Santos, Cordón García, \& Gómez Díaz, 2017) presentan un estudio que tiene como objetivo evaluar la calidad de los sitios web educativos centrados en el apoyo al aprendizaje en dos niveles educativos; la educación primaria y la secundaria. Este estudio exploratorio concluye que los sitios web educativos que tienen mejor clasificación con valores promedio más altos son los de Secundaria, y que, además, los creadores de estos recursos no son conscientes de la importancia de evaluar sus recursos a partir de la evaluación heurística, incluso antes de ponerlos en Internet. Se señala el fracaso de los requisitos funcionales y técnicos para quien concibe, publica y mantiene su contenido en línea, a menudo por falta de conocimiento en el manejo de estas nuevas tecnologías.

El tercer artículo (Tamayo \& Pérez-Martín, 2017) proporciona los resultados de una encuesta realizada a 82 docentes de 4 colegios de la zona sur de Madrid para saber qué esperan de los agentes conversacionales pedagógicos (Johnson, Rickel, \& Lester, 2000). 
El último artículo de este número está relacionado con los especiales que se desarrollaron en relación con el pensamiento computacional (García-Peñalvo, 2016; Wing, 2006) y la enseñanza de la informática y de la programación a estudiantes pre-universitarios (Balanskat \& Engelhardt, 2015; García-Peñalvo \& Cruz-Benito, 2016; García-Peñalvo, Reimann, Tuul, Rees, \& Jormanainen, 2016; Llorens-Largo, 2015) en las revistas ReVisión (García-Peñalvo, Llorens Largo, Molero Prieto, \& Vendrell Vidal, 2017) y Education in the Knowledge Society (Llorens Largo, García-Peñalvo, Molero Prieto, \& Vendrell Vidal, 2017) antes del verano. Sin embargo, al no ser una experiencia realizada en España, se optó por no incluirlo en dichos monográficos y se publica en este número. En dicho trabajo, Daniela Reimann y Christiane Maday (Reimann \& Maday, 2017), en el ámbito del proyecto europeo TACCLE 3 - Coding (García-Peñalvo, 2016a, 2016c; TACCLE 3 Consortium, 2017), defienden un enfoque interdisciplinario para aprender sobre el modelado computacional en procesos creativos y contextos estéticos, que cruce las fronteras de la tecnología, de la programación, de las artes y de los procesos de diseño en contextos significativos.

WYRED (netWorked Youth Research for Empowerment in the Digital society) (García-Peñalvo, 2016e; García-Peñalvo \& Kearney, 2016) is a H2020 European project (Ref. 727066) financed in the call Europe in a changing world - inclusive, innovative and reflective Societies (H2020-SC6-REV-INEQUAL-2016). The project consortium, which is leaded by GRIAL research group (García-Peñalvo, 2016b; GarcíaPeñalvo, et al., 2012) of the University of Salamanca, started the research work in November 2016, so we are approaching its first year. During this time, the project team has defined a novel research approach in the field of Social Sciences and that would be included in the concept of Open Science, with a focus more oriented to the citizen science (Ramírez-Montoya \& García-Peñalvo, 2018).

Specifically, WYRED aims to provide a framework for research in which young people, understanding young people, with a wide range of ages, can express and explore their perspectives and interests in relation to the digital society, together within a platform (García-Peñalvo \& Durán-Escudero, 2017) from which they can communicate their perspectives to other actors in an effective way, through innovative commitment processes. For this, a generative research cycle has been carried out, which has included networking activities, social dialogues, research activities defined for them, and phases of interpretation centred and directed by children and young people, which are emerging a diverse range of products, critical perspectives and other ideas for decision-making in relation to the needs of children and young people about digital society.

Figure 1 describes the research process that has been followed. In the first stage, related to the preparation, different actors have expressed their opinion on the most important aspects that they think influence the definition of society with the presence of technology. In the second phase, the social 
dialogues among young people are developed to define which issues are the most interesting ones to focus on. In the third phase of exploration, research projects are developed with an open approach to seek answers, both individually and collectively, to open questions. Finally, the fourth phase explains the results and offers recommendations to decision-makers. This cyclical approach will be repeated two more times until the end of the project. In more detail, Figure 2 presents this same cycle.

\section{Contents of this issue}

The first paper of this issue is entitled "Scientific Culture from the University. Research Competence Evaluation of Students Enrolled in the Summer Science Programs" (Grijalva Verdugo \& Urrea Zazueta, 2017). This work presents the results of a young researchers training program, Summer Science Program, in the Mexican state of Sinaloa.

Santos et al. (Santos, Cordón García, \& Gómez Díaz, 2017) presents a study that aims to evaluate the quality of educational websites focused on learning support of two degrees of education, Primary School and the High school. This exploratory study concludes that websites that had better ranking with higher average values were affected by High School websites, also that the creators of these resources are not conscience of the importance to assess their resources from heuristics evaluation, even before putting them on the Internet. It was noted the failure of the functional and technical requirements for who conceives, publishes and maintains their content online, often for lack of knowledge in handling these new technologies.

The third paper (Tamayo \& Pérez-Martín, 2017) presents the results of a survey of 82 teachers to know what they expect from the conversational pedagogical agents (Johnson, et al., 2000).

The last paper of this issue is related to the special issues about computational thinking (GarcíaPeñalvo, 2016d; Wing, 2006) and teaching programming and computer science to pre-university students (Balanskat \& Engelhardt, 2015; García-Peñalvo \& Cruz-Benito, 2016; García-Peñalvo, et al., 2016; Llorens-Largo, 2015) in the journals ReVisión (García-Peñalvo, et al., 2017) and Education in the Knowledge Society (Llorens Largo, et al., 2017) before summer. However, since it was not an experience in Spain, it was decided not to include it in these monographs and it is published in this issue now. In this work, Daniela Reimann y Christiane Maday (Reimann \& Maday, 2017), in the scope of TACCLE 3 - Coding European project (García-Peñalvo, 2016a, 2016c; TACCLE 3 Consortium, 2017), argue argue for an interdisciplinary approach to learn about computational modeling in creative processes and aesthetic contexts. It crosses the borders of programming technology, arts and design processes in meaningful contexts. 


\section{Referencias/References}

Balanskat, A., \& Engelhardt, K. (2015). Computing our future. Computer programming and coding Priorities, school curricula and initiatives across Europe. Retrieved from Brussels, Belgium: https:// goo.gl/i5aQiv

García-Peñalvo, F. J. (2016a). A brief introduction to TACCLE 3 - Coding European Project. In F. J. García-Peñalvo \& J. A. Mendes (Eds.), 2016 International Symposium on Computers in Education (SIIE 16). USA: IEEE. doi: http://doi.org/10.1109/SIIE.2016.7751876

García-Peñalvo, F. J. (2016b). Presentation of the GRIAL research group and its main research lines and projects on March 2016. Retrieved from http://hdl.handle.net/10366/127737

García-Peñalvo, F. J. (2016c). Proyecto TACCLE3 - Coding. In F. J. García-Peñalvo \& J. A. Mendes (Eds.), XVIII Simposio Internacional de Informática Educativa, SIIE 2016 (pp. 187-189). Salamanca, España: Ediciones Universidad de Salamanca.

García-Peñalvo, F. J. (2016d). What Computational Thinking Is. Journal of Information Technology Research, 9(3), v-viii.

García-Peñalvo, F. J. (2016e). The WYRED Project: A Technological Platform for a Generative Research and Dialogue about Youth Perspectives and Interests in Digital Society. Journal of Information Technology Research, 9(4), vi-x.

García-Peñalvo, F. J. (2017a). Mitos y Realidades del Acceso Abierto. Education in the Knowledge Society, 18(1), 7-20. doi: http://doi.org/10.14201/eks2017181720

García-Peñalvo, F. J. (2017b). Publishing in Open Access. Journal of Information Technology Research, 10(3), vi-viii.

García-Peñalvo, F. J., \& Cruz-Benito, J. (2016). Computational thinking in pre-university education. In F. J. García-Peñalvo (Ed.), Proceedings of the Fourth International Conference on Technological Ecosystems for Enhancing Multiculturality (TEEM'16) (Salamanca, Spain, November 2-4, 2016) (pp. 1317). New York, NY, USA: ACM. doi: http://doi.org/10.1145/3012430.3012490

García-Peñalvo, F. J., \& Durán-Escudero, J. (2017). Interaction design principles in WYRED platform. In P. Zaphiris \& A. Ioannou (Eds.), Learning and Collaboration Technologies. Technology in Education. 4th International Conference, LCT 2017. Held as Part of HCl International 2017, Vancouver, BC, Canada, July 9-14, 2017. Proceedings, Part II (pp. 371-381). Switzerland: Springer International Publishing. doi: http://doi.org/10.1007/978-3-319-58515-4_29 
García-Peñalvo, F. J., García de Figuerola, C., \& Merlo-Vega, J. A. (2010). Open knowledge: Challenges and facts. Online Information Review, 34(4), 520-539. doi: http://doi.org/10.1108/14684521011072963

García-Peñalvo, F. J., \& Kearney, N. A. (2016). Networked youth research for empowerment in digital society. The WYRED project. In F. J. García-Peñalvo (Ed.), Proceedings of the Fourth International Conference on Technological Ecosystems for Enhancing Multiculturality (TEEM'16) (Salamanca, Spain, November 2-4, 2016) (pp. 3-9). New York, NY, USA: ACM. doi: http://doi.org/10.1145/3012430.3012489

García-Peñalvo, F. J., Llorens Largo, F., Molero Prieto, X., \& Vendrell Vidal, E. (2017). Educación en Informática sub 18 (El<18). ReVisión, 10(2), 13-18.

García-Peñalvo, F. J., Reimann, D., Tuul, M., Rees, A., \& Jormanainen, I. (2016). An overview of the most relevant literature on coding and computational thinking with emphasis on the relevant issues for teachers. Belgium: TACCLE3 Consortium. doi: http://doi.org/10.5281/zenodo.165123

García-Peñalvo, F. J., Rodríguez-Conde, M. J., Seoane-Pardo, A. M., Conde-González, M. Á., Zangrando, V., \& García-Holgado, A. (2012). GRIAL (GRupo de investigación en InterAcción y eLearning), USAL. IE Comunicaciones. Revista Iberoamericana de Informática Educativa, 15, 85-94.

Grijalva Verdugo, A. A., \& Urrea Zazueta, M. L. (2017). Cultura científica desde la universidad. Evaluación de la competencia investigativa en estudiantes de Verano Científico. Education in the Knowledge Society, 18(3), 15-35. doi:http://doi.org/10.14201/eks20171831535.

Johnson, W., Rickel, J., \& Lester, J. (2000). Animated Pedagogical Agents: Face-to-Face Interaction in Interactive Learning Environments. Journal of Artificial Intelligence in Education, 11, 47-78.

Llorens Largo, F., García-Peñalvo, F. J., Molero Prieto, X., \& Vendrell Vidal, E. (2017). La enseñanza de la informática, la programación y el pensamiento computacional en los estudios preuniversitarios. Education in the Knowledge Society, 18(2), 7-17. doi: http://doi.org/10.14201/eks2017182717

Llorens-Largo, F. (2015). Dicen por ahí... que la nueva alfabetización pasa por la programación. ReVisión, 8(2), 11-14.

Ramírez-Montoya, M. S., \& García-Peñalvo, F. J. (2018). Co-creation and open innovation: Systematic literature review. Comunicar, 26(54).

Reimann, D., \& Maday, C. (2017). Enseñanza y aprendizaje del modelado computacional en procesos creativos y contextos estéticos. Education in the Knowledge Society, 18(3), 87-97. doi:http://doi. org/10.14201/eks20171838797

Santos, A. M., Cordón García, J. A., \& Gómez Díaz, R. (2017). The websites of primary and secondary 
schools in Portugal: an evaluation proposal. Education in the Knowledge Society, 18(3), 37-58. doi:http:// doi.org/1014201/eks20171833758

TACCLE 3 Consortium. (2017). TACCLE 3: Coding Erasmus + Project website. Retrieved from http:// www.taccle3.eu/

Tamayo, S., \& Pérez-Marín, D. (2017). ¿Qué esperan los Docentes de los Agentes Conversacionales Pedagógicos? Education in the Knowledge Society, 18(3), 59-85. doi:http://doi.org/10.14201/ eks20171835985

Wing, J. M. (2006). Computational Thinking. Communications of the ACM, 49(3), 33-35. doi: http://doi. org/10.1145/1118178.1118215

WYRED Consortium. (2017a). WYRED Research Cycle Infographic. European Union: WYRED Consortium. doi: http://doi.org/10.5281/zenodo.572622

WYRED Consortium. (2017b). WYRED Research Cycle Overview Infographic. European Union: WYRED Consortium. doi: http://doi.org/10.5281/zenodo.572633 